\title{
DIAGNOSTIC ACCURACY OF SERUM FERRITIN AND SOLUBLE SERUM TRANSFERRIN RECEPTOR, TAKING BONE MARROW IRON STAIN AS A GOLD STANDARD FOR IRON DEFICIENCY ANEMIA IN HETEROGENOUS GROUP OF PATIENTS
}

\author{
Tayyaba Ashiq, Ammara Hafeez, Abdus Sattar, Nasiruddin, Naureen Saeed*, Faiza Mushtaq \\ Combined Military Hospital Lahore/National University of Medical Sciences (NUMS) Pakistan, *Shalamar Medical \& Dental College Lahore Pakistan
}

\begin{abstract}
Objective: To determine the diagnostic accuracy of serum ferritin and soluble serum transferrin receptor (sTfR), taking bone marrow iron stain as a gold standard for iron deficiency anaemia in heterogeneous group of patients.

Study Design: Cross-sectional diagnostic accuracy study.

Place and Duration of Study: Department of Diagnostic, Combined Military Hospital Lahore, from Mar to Aug 2020.

Methodology: A total of 55 adult patients, of both genders, undergoing bone marrow examination for any reason were enrolled. Patients with known hemolytic condition (sickle cell anemia, megaloblastic anemia), taking erythropoietin/iron supplements, transfused red cell concentrate (RCC) recently or undergoing chemotherapy were excluded. Age, gender, clinical history and results of bone marrow examination, complete blood count (CBC), serum Ferritin and C-reactive protein (CRP) were recorded.

Results: Serum ferritin was found to be less sensitive (28\%) but more specific $(100 \%)$ for reflecting reduced bone marrow iron stores as compared to STfR (sensitivity: 60\%, specificity: 96.6\%). sTfR had highest likelihood ratio (15) and diagnostic accuracy $(80 \%)$. On Receiver Operator Characteristic (ROC) graph Transferrin index (AUC=0.908) showed maximum accuracy, followed by Ferritin (AUC=0.884) and sTfR (AUC=0.879).

Conclusion: Serum soluble transferring receptor (sTfR) and transferrin index has advantage over serum ferritin alone in predicting the bone marrow iron stores and differentiating iron deficiency anemia from anemia of chronic disease.
\end{abstract}

Keywords: Anemia of chronic disease (ACD), C-reactive protein (CRP), Ferritin, Iron deficiency anemia (IDA), Serum soluble transferring receptor (sTfR).

How to Cite This Article: Ashiq T, Hafeez A, Sattar A, Nasiruddin, Saeed S, Mushtaq F. Diagnostic Accuracy of Serum Ferritin and Soluble Serum Transferrin Receptor, Taking Bone Marrow Iron Stain as A Gold Standard for Iron Deficiency Anemia in Heterogenous Group of Patients. Pak Armed Forces Med J 2021; 71(6): 1920-1924. Doi: $\quad$ Dttps://doi.org/10.51253/pafmj.v6i6.6855

This is an Open Access article distributed under the terms of the Creative Commons Attribution License (https://creativecommons.org/licenses/by-nc/4.0/), which permits unrestricted use, distribution, and reproduction in any medium, provided the original work is properly cited.

\section{INTRODUCTION}

Iron deficiency anemia (IDA) and Anemia of chronic disease (ACD) are common types of anemia in clinical practice. ${ }^{1}$ Since long, serum ferritin has been used as an indicator of body iron stores. Serum Ferritin is highly specific but not a sensitive marker of iron deficiency. Being an acute phase reactant, Ferritin is falsely raised in patients with acute and chronic illnesses, masking iron deficiency. ${ }^{2}$ In the patients with co-morbids, it becomes difficult to discriminate between these two types of anemias i.e. IDA and ACD.

The accurate diagnosis of iron deficiency is essential for prompt diagnosis and successful management as it may be the sign of serious illness like GIT malignancy. ${ }^{3}$ There is a need of better marker of body iron stores, with increased sensitivity and specificity. In this context, serum soluble transferrin receptor (sTfR)

Correspondence: Dr Tayyaba Ashiq, Department of Chemical Pathology \& Endocrinology, CMH Lahore-Pakistan

Received: 08 Jun 2021; revision received: 25 Aug 2021; accepted: 25 Aug 2021 was evaluated. sTfR is a truncated monomer of tissue receptor which mediate cellular uptake of iron, which is released in plasma in transferrin cycle of iron uptake. ${ }^{4}$ It's a marker of erythropoietc activity thus less specific for iron deficiency. Erythroblast and reticulocytes are the main source of sTfR. ${ }^{5}$ Iron deficient cell expresses more sTfR and raised sTfR levels are seen in iron deficiency. Unlike ferritin, sTfR is not an acute phase reactant; hence it is not affected by acute or chronic illness, making it a sensitive marker of iron deficiency. ${ }^{6}$ Thus reducing the need of unnecessary bone marrow examination.

Transferrin index is calculated by dividing the sTfR with $\log$ of serum ferritin. ${ }^{7}$ The confounding factors which affect serum Ferritin and sTfR, does not affect its ratio, i.e. sTfRs/log Ferritin and it shows better correlation with bone marrow iron stores. In our study we compared serum ferritin, sTfR levels and transferrin index, which amongst them reflect the bone marrow iron stores better in heterogeneous group of patients. 


\section{METHODOLOGY}

This cross-sectional diagnostic accuracy study was carried out at Diagnostic Department of Combined Military Hospital Lahore, from March to August 2020, after taking approval from Research Review Board of the hospital (IRB-certificate No: 161/2020). The sample size was calculated from the following equation (A1) taken from a study by Flahault et al, on Sample size calculation in diagnostic test studies. ${ }^{8}$

$$
\frac{\left[z_{1}-\beta \sqrt{\pi(1-\pi)}+z_{1}-\alpha \sqrt{(\pi-\delta)(1-\pi+\delta)}\right.}{\delta^{2}}
$$

(A1) 55 patients were recruited using non-probability convenient sampling. Informed consent was obtained from them.

Inclusion Criteria: Patients undergoing bone marrow examination for the first time for any reason like PUO, unexplained anemia, bicytopenia, weight loss or suspected malignancy were included in the study.

Exclusion Criteria: We excluded the patients with sickle cell anemia, megaloblastic anemia, on erythropoietin treatment or taking iron supplementation, red cell concentrate (RCC) transfused within last 3 months. Patients currently on chemotherapy or have taken chemotherapy during last one year were also excluded. Patients with diluted marrow aspirate were excluded from the study.

Demographic and relevant clinical data was recorded. Bone marrow aspiration and trephine biopsies were taken from posterior superior iliac spine under local anesthesia and strict aseptic measures. 1$2 \mathrm{ml}$ of bone marrow aspirate was sucked out using 18 gauge bone marrow aspiration needle attached to $20 \mathrm{ml}$ syringe. Aspirate was examined for fragments and slides were prepared at bedside. These slides were stained with Leishman and Geimsa stain for cytological examination. Perls staining was done for intracellular and extracellular iron. The iron appears bright blue against red background. Bone marrow iron was graded into six levels according to Bain, et al, Bone marrow Pathology. ${ }^{9}$ These six grades were numbered in increasing order of iron stain, starting from $0=$ absent, $1=$ trace, $2=$ reduced, $3=$ present, $4=$ increased, $5=$ markedly increased very large clumps with extra-cellular iron.

Blood samples $(3 \mathrm{ml})$ were taken in EDTA tubes and analyzed immediately for complete blood count using Sysmex Kx21. Peripheral smear were examined manually. Approximately $3 \mathrm{ml}$ blood was collected in gel tubes from each patient for analysis of soluble serum transferrin receptor (sTfR), ferritin and C-reactive protein (CRP). Centrifugation was done at 3500 rpm for 3 minutes to separate the serum. Sera were kept at $2-8^{\circ} \mathrm{C}$, in case there was any delay in analysis. Quantitative analysis of sTfR and CRP was done using Roche Cobas C-501 random access chemistry autoanalyzer. Ferritin was analyzed using electrochemiluminescence immunoassay on Roche Cobas e-411 autoanalyzer.

Anemia was defined as $\mathrm{Hb}<11.5 \mathrm{~g} / \mathrm{dL}$ in females and $<13.5 \mathrm{~g} / \mathrm{dL}$ in males. $43(78 \%)$ were anemic and $12(21 \%)$ were non-anemic 10 . Based on hemoglobin $(\mathrm{Hb})$ level, patients were labeled with anemia or noanemia. Patients with anemia were further divided into 3 groups, iron deficiency anemia (IDA), anemia of chronic disorder (ACD) and mixed anemia (IDA+ ACD). Those patients, who had absent or trace/reduced bone marrow iron; were labeled with iron deficiency anemia (IDA). Patients who had raised CRP and/ or TLC were categorized under anemia of chronic disorder. Patients who had both were classified under mixed anemia (IDA+ACD) group. Transferrin index was calculated by dividing sTfR in $\mathrm{mg} / \mathrm{dL}$ by $\log$ of ferritin in $\mathrm{ng} / \mathrm{mL}$. Sensitivity, specificity, positive predictive value, negative predictive value, likelihood ratio and diagnostic accuracy for serum ferritin, sTfR and transferrin index were calculated using respective formulas. Statistical Package for the social sciences (SPSS) version 23 was used to analyze data. Receiver Operator Characteristic (ROC) graph was made for the area under the curve (AUC) of the studied parameters to reflect the bone marrow iron stores. One-way ANOVA test was used to observe the difference of mean of three studied parameters between the groups i.e. IDA, ACD, Mixed anemia group. The $p$-value of $\leq 0.05$ was considered.

\section{RESULTS}

Out of 55 enrolled patients, $38(69 \%)$ were males and $17(31 \%)$ were females. The mean age was $45.82 \pm$ 21.56 years. Minimum and maximum hemoglobin level was recorded to be $5.6 \mathrm{~g} / \mathrm{dL}$ and $16.5 \mathrm{~g} / \mathrm{dL}$ with the mean of $10.70 \pm 2.73 \mathrm{mg} / \mathrm{dL}$. There were 16 cases of pure IDA, 18 cases of pure ACD and only 9 cases of mixed anemia.

Out of 16 patients with IDA, $9(56.2 \%)$ had totally absent, $5(31.2 \%)$ had trace and only $2(12.5 \%)$ reduced iron in the bone marrow. Among 9 cases of mixed anemia, $2(22.2 \%)$ had trace, $5(55.5 \%)$ had reduced and $2(22.2 \%)$ had increased stainable iron in the bone marrow (Table-I). None of ACD case had reduced 
marrow iron. Serum ferritin was $28 \%$ sensitive but $100 \%$ specific for reflecting reduced bone marrow iron stores. However, sTfR had sensitivity: $60 \%$ and specificity: $96.6 \%$ (Table-II). The sensitivity and specificity of the transferrin index was calculated to be $64 \%$ and $83 \%$ respectively. Among three studied parameters, sTfR had diagnostic accuracy of $80 \%$, transferring index $(74.5 \%)$ and ferritin $(67.2 \%)$ (Table-II).

Table-I: Ferritin, Soluble Serum Transferring Receptor (sTfR), Transferring Index [sTfR/log ferritin] values in the study participants

\begin{tabular}{l|c|c}
\hline $\begin{array}{l}\text { Parameters } \\
(\mathbf{n}=55)\end{array}$ & $\begin{array}{c}\text { Bone } \\
\text { Marrow iron } \\
\text { reduced/ } \\
\text { trace/absent }\end{array}$ & $\begin{array}{c}\text { Bone marrow } \\
\text { iron stores } \\
\text { present/ } \\
\text { increased }\end{array}$ \\
\hline Ferritin reduced & $7(12.7 \%)$ & - \\
\hline Ferritin WNL* increased & $18(32.7 \%)$ & $30(54.5 \%)$ \\
\hline $\begin{array}{l}\text { Soluble serum transferrin } \\
\text { receptor increased }\end{array}$ & $15(27.2 \%)$ & $1(1.81 \%)$ \\
\hline $\begin{array}{l}\text { Soluble serum transferrin } \\
\text { receptor WNL*/reduced }\end{array}$ & $10(18.1 \%)$ & $29(52.7 \%)$ \\
\hline Transferrin index >2 & $16(29 \%)$ & $5(9 \%)$ \\
\hline Transferrin index <2 & $9(16.3 \%)$ & $25(45.4 \%)$ \\
\hline${ }^{*} W N L=$ within normal limits & \multicolumn{2}{|l}{}
\end{tabular}

The receiver operator characteristic (ROC) graph was made to see the area under the curve (AUC) of the studied parameters to reflect the bone marrow iron stores. Transferrin index (AUC $=0.908)$ showed maximum accuracy, followed by ferritin (AUC $=0.884$ ) and sTfR (AUC=0.879) (Figure-1 \& 2).
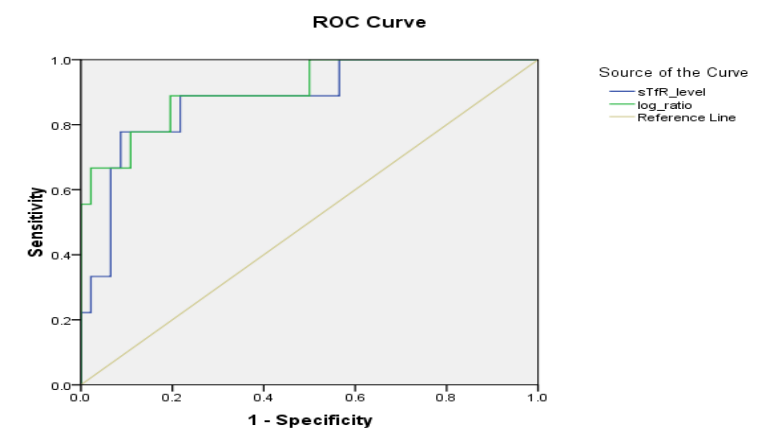

Figure-1: ROC of sTfR\&transferrin index (AUC of $\mathrm{sTfR}=$ 0.879, AUC of Tansferrin index $=0.908$ ).

Statistically significant difference in the mean of $\operatorname{sTfR}(p=0.001)$ and tranferrin index $(p=0.006)$ was observed between groups i.e. IDA, ACD and mixed deficiency anemia. However, for serum ferritin this difference was not statistically significant $(p=0.323)$ TableIII \& IV.

\section{DISCUSSION}

In the clinical practice, the most commonly encountered iron deficiency state is associated with the underlying inflammatory conditions. This usually manifests as presence of mixed patterns of iron variables. It is a daily dilemma especially in tertiary care hospitals, to differentiate between the anemia of chronic disorder and iron deficiency anemia with underlying inflammatory cause.

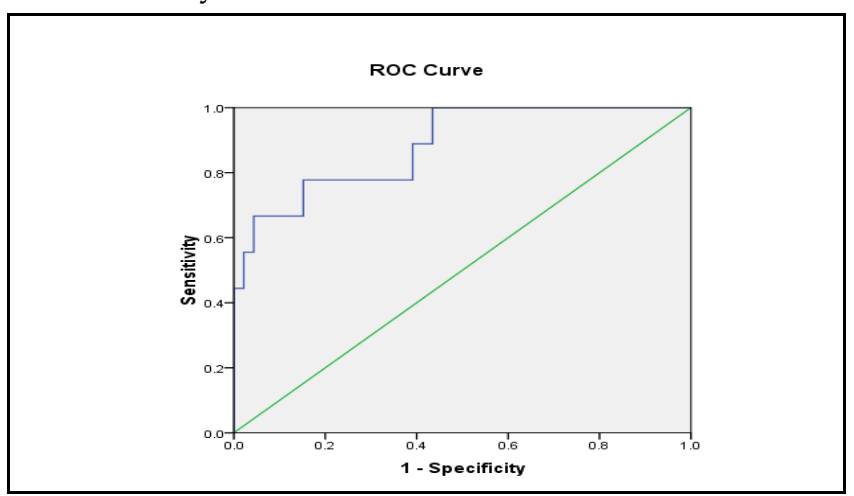

Figure-2: ROC graph of ferritin ( AUC= 0.884).

In our study serum ferritin was found to be less sensitive $(28 \%)$ but more specific $(100 \%)$ for reflecting reduced bone marrow iron stores as compared to sTfR (sensitivity: $60 \%$, specificity: $96.6 \%$ ). sTfR had highest likelihood ratio of positive test i.e. ${ }^{15}$ It means that the probability of having iron deficiency is very high when sTfR is raised. Among three studied parameters, sTfR had highest diagnostic accuracy of $80 \%$, followed by transferring index $(74.5 \%)$ and ferritin $(67.2 \%)$.

Alan E. Mast and coworkers studied the clinical utility of sTfR in different populations and found out that diagnostic sensitivity and specificity of sTfR (at a diagnostic cutoff of $>2.8 \mathrm{mg} / \mathrm{L}$ ) were $92 \%$ and $84 \%$, respectively, with a positive predictive value of $42 \%$ in anemic population. ${ }^{11}$ They concluded that in patients with no anemia, sTfR does not provide any additional information over ferritin but it may be useful in patients with anemia and co-morbids when used conjunction to routine investigations. Their findings were in line with our findings. Skikne et al did a research on 145 patients with anemia and concluded that by using all three parameters in combination, the ability to detect the patients of IDA increased, from $41 \%$ (ferritin alone) to $92 \%$ (ferritin, sTfR and transferrin index). Thus, use of sTfR and the transferrin index improves detection of IDA, particularly in situations where routine markers provide equivocal results. ${ }^{12}$

In a study conducted by Junca et al, it was found that all the patients with iron deficiency anemia had a raised Serum TfR values. In contrast to our findings, they concluded that in patients having anaemia of chronic disease, sTfR cannot be accurately used to assess 
Table-II: Sensitivity, specificity, positive predictive value and negative predictive value of serum ferritin, stfr\& transferrin index.

\begin{tabular}{|c|c|c|c|}
\hline Diagnostic Parameters & Ferritin & $\begin{array}{c}\text { Soluble serum Transferrin } \\
\text { Receptor (sTfR) }\end{array}$ & $\begin{array}{l}\text { Transferring index } \\
\text { (sTfR/log ferritin) }\end{array}$ \\
\hline Sensitivity=True Positive/( True Positive +False Negative) & $28 \%$ & $60 \%$ & $64 \%$ \\
\hline Specificity=True Negative /(True Negative + False Positive) & $100 \%$ & $96.6 \%$ & $83 \%$ \\
\hline $\begin{array}{l}\text { Positive Predictive Value }=\text { True Positive } / \text { (True Positive }+ \\
\text { False Positive) }\end{array}$ & $100 \%$ & $93.5 \%$ & $76 \%$ \\
\hline $\begin{array}{l}\text { Negative Predictive Value }=\text { True Negative } / \text { (True Negative } \\
+ \text { False Negative) }\end{array}$ & $62.5 \%$ & $74.4 \%$ & $73 \%$ \\
\hline Likelihood ratio for positive test= Sensitivity/1-specificity & - & 15 & 3.76 \\
\hline Likelihood ratio for negative test= Specificity /1-sensitivity & 1.38 & 2.4 & 2.3 \\
\hline Diagnostic accuracy & $67.2 \%$ & $80 \%$ & $74.5 \%$ \\
\hline
\end{tabular}

Table-III: Comparison of Serum Ferritin, sTfR and transferrin index among various groups.

\begin{tabular}{l|c|c|c|c|c}
\hline Parameters & $\begin{array}{c}\text { Non anemic } \\
(\mathbf{n = 1 2})\end{array}$ & $\begin{array}{c}\text { Iron deficiency anemia } \\
\text { (IDA)(n=16) }\end{array}$ & $\begin{array}{c}\text { Anaemia of chronic } \\
\text { disease (ACD)(n=18) }\end{array}$ & IDA+ACD(n=9) & $\boldsymbol{p}$-value \\
\hline Serum Ferritin levels & $377.5 \pm 651.1$ & $186.6 \pm 366.8$ & $502.3 \pm 533.0$ & $458.2 \pm 455.9$ & 0.323 \\
\hline sTfR & $3.1 \pm 1.1$ & $7.9 \pm 6.2$ & $3.0 \pm 1.2$ & $5.1 \pm 2.8$ & 0.001 \\
\hline Transferrin index & $1.6 \pm 0.9$ & $6.7 \pm 8.4$ & $1.2 \pm 0.6$ & $2.4 \pm 1.7$ & 0.006 \\
\hline
\end{tabular}

Table-IV: Post Hoc Tukey's Test for intergroup comparison.

\begin{tabular}{l|c|c|c|c|c|c}
\hline $\begin{array}{l}\text { Group } \\
\text { Comparison }\end{array}$ & $\begin{array}{c}\text { Non Anaemic } \\
\text { Vs. IDA }\end{array}$ & $\begin{array}{c}\text { Non AnaemicVs. } \\
\text { ACD }\end{array}$ & $\begin{array}{c}\text { Non Anaemic } \\
\text { Vs. IDA+ACD }\end{array}$ & $\begin{array}{c}\text { IDAVs. } \\
\text { IDA+ACD }\end{array}$ & $\begin{array}{c}\text { IDAVs. } \\
\text { ACD }\end{array}$ & $\begin{array}{c}\text { ACDVs. } \\
\text { IDA+ACD }\end{array}$ \\
\hline Transferrin index & 0.020 & 0.900 & 0.900 & 0.100 & 0.006 & 0.900 \\
\hline sTfR & 0.006 & 1.00 & 0.500 & 0.200 & 0.001 & 0.400 \\
\hline
\end{tabular}

the iron levels due to its lower sensitivity and specificity as compared to the bone marrow aspiration and Perls staining, which remains the gold standard. ${ }^{13}$ Similarly, in India a case control study was conducted on patients with anemia along stage $5 \mathrm{CKD}$, they conclude that owing to complexity of iron metabolism in CKD, sTfR cannot be used as a reliable marker of iron deficiency anemia. ${ }^{14}$

Harms et al, concluded that in cases of complicated anaemias, there is a limited validity of the commonly used biomarkers to assess iron metabolism. For the accurate differentiation of anaemia due to inflammation, sTfR derived indices should be employed rather than measuring sTfR alone. ${ }^{15}$ Van et al, however showed contradictory results and revealed that ferritin and sTfR/ferritin ratio has significant predictive values for the differentiation of iron deficiency anaemia from other causes of anaemia. He further suggested that ferritin was the only independent and significant predictor of iron deficiency anemia with a cut-off point of 32 $\mu \mathrm{g} / 1$ (sensitivity $79.2 \%$, specificity $96.9 \%$ ). ${ }^{16}$

In our study ROC analysis for serum ferritin showed that AUC was 0.884, for sTfR is 0.879 , and of tansferrin index was 0.908 . This showed that sTfR reflects bone marrow iron stores better than the serum ferritin levels but transferrin index remained the accurate marker. By definition from $\mathrm{WHO}$, a low serum ferritin is described when it is $<15 \mu \mathrm{g} / 1$ in adults and
$<12 \mu \mathrm{g} / 1$ in children. A level of $35 \mu \mathrm{g} / 1$ has been set as the most accurate with $92 \%$ sensitivity and $98 \%$ specificity. ${ }^{17}$ Serum ferritin levels are affected by various factors including the physical and demographic variables. Particular importance is given to old age, obesity and concomitant comorbid conditions which are all interlinked and the most common features of patients having inflammatory conditions leading to iron deficiency anemia. ${ }^{18}$

Remacha et al, studied the differentiation of iron deficiency anaemia having features of inflammatory disease using sTfR levels and concluded that sTfR yield a sensitivity of $92 \%$ and specificity of $81 \%$ when the cut-off point used was $4.7 \mathrm{mg} / \mathrm{L} .{ }^{19}$ Apriyanti et al, studied the diagnostic accuracy of serum ferritin levels in detecting iron deficiency anaemia in children under five years of age and concluded that if $<32.4 \mu \mathrm{g} / 1$ was used as a cut off value then serum ferritin had a sensitivity of $62.1 \%$ and specificity of $50.8 \% .{ }^{20}$ Another meta-analysis revealed that both sTfR and sTfR index showed a significant odds ratio $(22.9,95 \%$ confidence interval, 9.6-55.0 and 9.5, 95\% CI, 5.0-18.1 respectively). The sensitivity was $86 \%$, specificity was $75 \%$ with an AUC value of 0.91221 .

Seema et al, in their study concluded that the diagnostic accuracy of sTfR was $85.4 \%$ which was comparatively lower than sTfR- serum ferritin index $(91.57 \%)$ and higher than serum ferritin alone $(75.09 \%)$ 
in cases of iron deficiency anaemia. Where as in cases of anaemia of chronic disease the diagnostic accuracy of sTfR was higher $(91.03 \%)$ than both the sTfR-Serum ferritin index $(89.86 \%)$ and serum ferritin $(79.71 \%) .22$ Ejaz et al, in his study showed that the positive and negative predictive value of STfR was $100 \%$ in cases of iron deficiency anaemia and in anaemia of chronic disease it was $100 \%$ and $74.1 \%$ respectively. He also concluded that if cut off of $90 \mathrm{ng} / \mathrm{ml}$ was used for serum ferritin levels then it can effectively exclude cases of iron deficiency anaemia especially those having other chronic inflammatory conditions. ${ }^{23}$

\section{LIMITATION OF STUDY}

It's a small, single center study in which few biochemical parameters were studied. For better analysis, large scale prospective study should be done.

\section{CONCLUSION}

sTfR and Transferrin index has advantage over serum ferritin alone in predicting the bone marrow iron stores. sTfR has good sensitivity $(60 \%)$, specificity $(96.6 \%)$, positive predictive value $(93.5 \%)$ and highest positive likelihood ratio (15) and diagnostic accuracy (80\%). sTfR and transferring index are superior to the old marker i.e. serum ferritin for differentiating iron deficiency anemia from anemia of chronic disease.

\section{Conflict of Interest: None.}

\section{Authors' Contribution}

TA: Designed the study, collection \& analyzed the data, wrote initial draft of paper, AH: Performed the bone marrow aspiration prepared \& analyzed the study, AS: Designed the study, N: Studied and diagnosed the bone marrow cases, revised and edited the preper, NS: Independently reviewed the bone marrow cases, FM: Data collection and interpretation reviewed \& edited the paper.

\section{REFERENCES}

1. Camaschella C. New insights into iron deficiency and iron deficiency anemia. Blood Rev 2017; 31(4): 225-233.

2. Daru J, Colman K, Stanworth SJ, La-Salle B, Wood EM, Pasricha SR. Serum ferritin as an indicator of iron status: what do we need to know? Am J Clin Nutr 2017; 106(suppl-6): 1634S-1639S.

3. Al-Fatlawi AC. A Review on Iron Deficiency Anemia. Kerbala J Pharm Sci 2021; 1(19): 10-17.

4. Vázquez-López MA, López-Ruzafa E, Ibáñez-Alcalde M, MartínGonzález M, Bonillo-Perales A, Lendínez-Molinos F. The usefulness of reticulocyte haemoglobin content, serum transferrin receptor and the sTfR-ferritin index to identify iron deficiency in healthy children aged 1-16 years. Europ J Pediatr 2019; 178(1): 41-49.

5. Srinivasan B, Finkelstein JL, O'Dell D, Erickson D, Mehta S. Rapid diagnostics for point-of-care quantification of soluble transferrin receptor. eBio Med 2019; 42(2352-3964): 504-510.

6. Ratnaningsih T, Sukirto NW, Wahyuningsih AT. Soluble Transferrin Receptor (sTfR) Identifies Iron Deficiency Anemia (IDA) in Pulmonary Tuberculosis Patients. Acta Med Indon 2020; 52(4): 334-343.
7. Krawiec P, Pac-Kożuchowska E. Soluble transferrin receptor and soluble transferrin receptor/log ferritin index in diagnosis of iron deficiency anemia in pediatric inflammatory bowel disease. Dig Liver Dis 2019; 51(3): 352-357.

8. Flahault A, Cadilhac M, Thomas G. Sample size calculation should be performed for design accuracy in diagnostic test studies. J Clin Epidemiol 2005; 58(8): 859-862.

Bain BJ, Clark DM, Wilkins BS. Bone marrow pathology. 4th ed. Chichester, England: Wiley-Blackwell; 2010 [Internet] Available at: https://www.worldcat.org/title/bone-marrow-pathology/ oclc/434319089

Hoffbrand A, Moss P. Essential haematology. 7th ed. Chichester, West Sussex: Wiley Blackwell; 2016, Available at: https://www. worldcat.org/title/hoffbrands-essentialhaematology/oclc/910009732

9. Mast AE, Blinder MA, Gronowski AM, Chumley C, Scott MG. Clinical utility of the soluble transferrin receptor and comparison with serum ferritin in several populations. $\mathrm{Cl}$ Chem 1998; 44(1): 45-51.

10. Skikne BS, Punnonen K, Caldron PH, Bennett MT, Rehu M, Gasior GH, et al. Improved differential diagnosis of anemia of chronic disease and iron deficiency anemia: a prospective multicenter evaluation of soluble transferrin receptor and the sTfR/ $\log$ ferritin index. Am J Hematol 2011; 86(11): 923-927.

11. Gupta S, Uppal B, Pawar B. Is soluble transferrin receptor a good marker of iron deficiency anemia in chronic kidney disease patients?. Ind J Nephrol 2009; 19(3): 96.

12. Juncà J, Fernández-Avilés F, Oriol A, Navarro JT, Millá F, Sancho $\mathrm{JM}$, et al. The usefulness of the serum transferrin receptor in detecting iron deficiency in the anemia of chronic disorders. Haematol 1998; 83(8): 676-680.

13. Harms K, Kaiser T. Beyond soluble transferrin receptor: old challenges and new horizons. Best Pract Res Cl En 2015; 29(5): 799-810.

14. Van-Tellingen A, Kuenen JC, De-Kieviet W, Van-Tinteren H, Kooi ML, Vasmel WL. Iron deficiency anaemia in hospitalised patients: value of various laboratory parameters: differentiation between IDA and ACD. Nether J Med 2001; 59(6): 270-279.

15. Dignass A, Farrag K, Stein J. Limitations of serum ferritin in diagnosing iron deficiency in inflammatory conditions. Int J Chronic Dis 2018; 2018(Article ID 9394060): 11-15.

16. Jamali NH, Jamali AH, Khand AA, Mahesar H, Arain MI. Factors affecting the body mass index, haemoglobin and serum ferritin level in students. Am J blood Res 2017; 7(3): 18.

17. Remacha AF, Sarda MP, Parellada M, Ubeda J, Manteiga R. The role of serum transferrin receptor in the diagnosis of iron deficiency. Haematolog 1998; 83(11): 963-966.

18. Apriyanti WS, Sutaryo S, Mulatsih S. Serum ferritin to detect iron deficiency in children below five years of age. Paediatr Indo 2013; 53(3): 150-154.

19. Infusino I, Braga F, Dolci A, Panteghini M. Soluble transferrin receptor (sTfR) and sTfR/log ferritin index for the diagnosis of iron-deficiency anemia a meta-analysis. Am J Clin Pathol 2012; 138(5): 642-649.

20. Nadeem S, Shah S, Iqbal T, Iqbal Z, Hanif E. Serum transferrin receptor, serum ferritin and serum transferrin receptor-ferritin index in adults with iron deficiency anaemia. J Ayub Med Coll Abbottabad 2011; 23(3): 44-46.

21. Hanif E, Ayyub M, Anwar M, Ali W, Bashir M. Evaluation of serum transferrin receptor concentration in diagnosing and differentiating iron deficiency anaemia from anaemia of chronic disorders. J Pak Med Assoc 2005; 55(1): 13-16. 